\title{
Análise fonológica dos erros da apraxia adquirida de fala**
}

\author{
Phonological error analysis of acquired speech apraxia
}

\author{
Maysa Luchesi Cera* \\ Karin Zazo Ortiz**
}

*Fonoaudióloga. Mestranda em Distúrbios da Comunicação Humana pela Unifesp. Endereço para correspondência:

Rua Botucatu, 802 - São Paulo - SP CEP 04023-900

(mamaysa@hotmail.com).

**Fonoaudióloga. Pós Doutorado em Neurociências pela Universidade Federal de São Paulo. Professor Doutor Adjunto do Departamento de Fonoaudiologia da Universidade Federal de São Paulo.

*** Trabalho Realizado no Departamento de Fonoaudiologia da Universidade Federal de São Paulo.

Artigo Original de Pesquisa

Artigo Submetido a Avaliação por Pares

Conflito de Interesse: não

Recebido em 25.03.2008.

Revisado em 22.07.2008; 27.01.2009;

30.03.2009.

Aceito para Publicação em 04.05.2009.

\begin{abstract}
Background: the phonological characterization of the errors present in the speech of individuals with speech apraxia can elucidate several aspects of this disorder and consequently lead to the development of effective therapeutic interventions. Generally, studies that have characterized the errors present in speech apraxia were developed in other languages other than the Brazilian Portuguese (BP). The existing national literature about this theme is based on these studies. Aim: to present the phonological analysis of the errors present in the speech of individuals with speech apraxia, speakers of the BP language. Method: 20 adults with speech apraxia were evaluated. The analysis of phonological errors, such as substitution and omission was made. Results: a few of the most affected phonemes in the speech of apraxic individuals $(/ \mathrm{b} /, / \lambda / \mathrm{e} / 3 /)$, speakers of the BP language, were different from those usually described in international studies. Conclusion: results suggest that the errors present in the speech of apraxic individuals can suffer the influence of language once the most frequent errors found in the present study were different from those described in the international literature.
\end{abstract}

Key Words: Articulation Disorders; Apraxias; Diagnosis.

\section{Resumo}

Tema: a caracterização fonológica dos erros presentes na fala do indivíduo com apraxia de fala pode fornecer dados para uma melhor compreensão deste distúrbio e, conseqüentemente, para o desenvolvimento de propostas terapêuticas. Em geral, os estudos que analisam fonologicamente a fala do indivíduo com apraxia de fala são internacionais e a literatura nacional que aborda esse distúrbio da fala se baseia nestes trabalhos. Objetivo: realizar análise fonológica dos erros presentes na fala do indivíduo com apraxia de fala, falante do Português, falado no Brasil. Método: participaram do estudo 20 adultos com apraxia de fala. Foi realizada análise fonológica dos erros do tipo substituição e omissão, obtidos através do protocolo de avaliação da apraxia verbal e não-verbal. Resultados: alguns dos fonemas mais freqüentemente acometidos pelos erros de fala dos apráxicos falantes da língua portuguesa (/b/, $/ \lambda / \mathrm{e} / 3 /$ ) revelaram diferença dos achados de estudos internacionais. Conclusão: verificou-se que os erros presentes na fala dos indivíduos com apraxia de fala parecem sofrer interferência específica da língua, uma vez que os fonemas mais freqüentemente produzidos com erro diferiram dos descritos em estudos internacionais.

Palavras-Chave: Transtornos da Articulação; Apraxias; Diagnóstico. 


\section{Introduction}

The apraxia of speech is an articulation disorder resulting from impairment, as the result of brain damage, of the capacity to program the positioning of speech musculature and the sequencing of muscle movements for the volitional production of phonemes 1 .

Many previous studies 1-12 have described the manifestations of this disorder as well as the most frequent phonological errors. However, these reports have typically been based on international studies involving English language speakers.

The phonological characterization of speech errors produced by Brazilian Portuguese speakers with apraxia of speech may yield valuable data to further the understanding of this disorder and allow enhanced treatment to be devised. Moreover, specific problems in the planning and production of the phonemes contained in Brazilian Portuguese can be analyzed and considered.

Therefore, the aim of the present study was to perform and present a phonological analysis of substitution and omission type errors produced by Brazilian-Portuguese speaking apraxics.

\section{Method}

This study was approved by the Research Ethics Committee of the Federal University of São Paulo (UNIFESP) under protocol number 1105/07. All participants signed a free and informed consent form.

Participants were selected from patients diagnosed with apraxia of speech and seen in 2007 at the outpatient unit for acquired speech and language disorders of the Speech Therapy sector of Unifesp.

For study inclusion, subjects had to present a neurological diagnosis of a single lesion to the lefthemisphere and be speakers of Brazilian Portuguese. The sample also included apraxics with associated aphasia since few patients present purely with apraxia of speech only.

Individuals who presented marked expression deficit, characterized by suppression or severely reduced oral capacity; impaired auditory comprehension preventing task execution; clinical history or diagnosis of previous neurological conditions (such as epilepsy, head trauma with loss of consciousness of longer than 15 minutes); uncorrected hearing or visual disturbances; history of severe depression or psychiatric disorders; and use of psychotropic drugs, were excluded.

The final sample comprised 20 adults aged between 41 and 80 years, with 11 men and 9 women.

Data was first gathered through anamneses (personal details and neurologic history).

Speech assessment was carried out using the verbal praxic component of the protocol for evaluation of verbal and non-verbal apraxia 13, which entails tests of word and sentence repetition, automatic and spontaneous speech and oral reading aloud. The "Cookie Theft" test from the Boston Diagnostic Aphasia Examination was used to elicit spontaneous speech production 14 .

Patient speech was digitally recorded using a SONY MP3 player and concomitantly transcribed.

Phonological analysis was carried out (quantitative and qualitative) on substitution and omission errors, which were the most frequent types of speech error committed by individuals assessed in this study.

Assessment of apraxia should take in to account all factors which may influence speech performance. Some of these factors include: errors are more frequent in words comprising phonemes less commonly used in the language, which are longer or that contain consonant clusters, words with fricatives or phonemes with more distant articulation positions. Thus, phonemes should appear in words of different length and frequency in the language, and must also appear in a range of positions in the words presented. However, all phonemes do not occur at the same rate in the language and this presents difficulties in selecting words that incorporate all these variables. Therefore, in order to involve all these variables the tasks presented are not phonetically balanced.

Thus, to calculate the percentage error for each phoneme, the number of times the phoneme should occur in each sample must first be ascertained. This procedure was performed to prevent a phoneme which was more frequently produced during the assessment, from presenting a commensurately higher number of errors, or vice-a-versa.

With regard to substitution type errors, the number of substitutions per phoneme was tallied across the whole speech sample for all subjects assessed (consonant segments, semivowels and vowels) and the occurrence of each type of substitution by phoneme was calculated. Concerning omission type errors, the phonemes associated with this type of error were identified and the frequency of error occurrence per phoneme calculated, where the analysis was based on the whole sample assessed. 
After the data was gathered, descriptive statistical analysis was carried out. Analysis was performed using version 11.5.1 of the SPSS (Statistical Package for the Social Sciences) statistical package for Windows.

\section{Results}

Characterization of the sample:

Three patients were diagnosed with hemorrhagic cerebral stroke while the remainder had suffered ischemic strokes. All apraxic patients bar one were also aphasics. In terms of lesion site, six patients presented temporoparietal lesions, four fronto-temporal, three fronto-parietal, two parietal, two frontal, one temporal, one temporo-parietooccipital and one parietal-occipital.

Phonological analysis of errors

In overall analysis of all speech samples assessed, the phonemes substituted in more than
$5 \%$ of cases, and substitution frequency were: consonant segments: /b/ 6.9\%,/g/ 9.2\%, /v/ 5.2\%, / $\int / 5.5 \%, / 3 / 12.2 \%, / \lambda / 20 \%$; in code (final consonant): /r/ 5.8\%; consonant cluster: /1/ 25.9\%.

Table 1 depicts the frequency of the types of substitutions of phonemes most frequently affected by this error, where the frequency of each phonemic substitution was calculated based on the total substitutions of the phoneme, i.e. the number of times the phoneme was produced with substitution; whereas the frequency of the type of substitution in speech was calculated based on the total possibility of the occurrence of the phoneme in the overall sample of speech of the subjects, which included both productions with errors and total correct productions of the phoneme, i.e. the total number of times the phoneme should occur in the speech samples assessed.

Table 2 shows the phonemes omitted in more than $5 \%$ of all speech samples analyzed, together with their respective omission frequencies, calculated based on the number of times the phoneme should have been produced in the sample.

TABLE 1. frequency of phoneme substitution types in patients with apraxia of speech.

\begin{tabular}{|c|c|c|c|}
\hline Phonemes & Substitution Type & Frequency of Each Phonemic Substitution (\%) & Frequency in Speech \\
\hline \multicolumn{4}{|l|}{ Consonant segments } \\
\hline \multirow[t]{5}{*}{$/ \mathrm{b} /$} & $/ \mathrm{b} /->/ \mathrm{p} /$ & 80.8 & 5.5 \\
\hline & $/ \mathrm{b} /->/ \mathrm{m} /$ & 3.8 & 0.3 \\
\hline & $/ \mathrm{b} /->/ \mathrm{v} /$ & 7.7 & 0.5 \\
\hline & $/ \mathrm{b} /->/ \mathrm{d} /$ & 3.8 & 0.3 \\
\hline & $/ \mathrm{b} /->/ \mathrm{g} /$ & 3.8 & 0.3 \\
\hline \multirow[t]{4}{*}{$/ \mathrm{g} /$} & $/ g /->/ t /$ & 5.2 & 0.5 \\
\hline & $/ \mathrm{g} /->/ 1 /$ & 5.2 & 0.5 \\
\hline & $\mid \mathrm{g} /->/ \mathrm{f} /$ & 5.2 & 0.5 \\
\hline & $\mid \mathrm{g} /->/ \mathrm{k} /$ & 84.3 & 7.7 \\
\hline \multirow[t]{5}{*}{$/ \mathrm{v} /$} & $/ \mathrm{v} / \mathrm{-} / \mathrm{f} /$ & 45.4 & 2.3 \\
\hline & $/ \mathrm{v} /->/ \mathrm{d} /$ & 9.1 & 0.5 \\
\hline & $/ \mathrm{v} /->/ \mathrm{t}$ & 9.1 & 0.5 \\
\hline & $/ \mathrm{v} /->/ \mathrm{b} /$ & 27.3 & 1.4 \\
\hline & $/ \mathrm{v} /->/ \mathrm{p} /$ & 9.1 & 0.5 \\
\hline \multirow[t]{3}{*}{$/ d /$} & $/ \mathrm{J} /->/ \mathrm{k} /$ & 25.0 & 1.4 \\
\hline & $\mid \mathrm{J} /->/ \mathrm{f} /$ & 25.0 & 1.4 \\
\hline & $\mid \mathrm{j} /->/ \mathrm{s} /$ & 50.0 & 2.7 \\
\hline \multirow[t]{5}{*}{$/ 3 /$} & $|z /->| z \mid$ & 10.5 & 1.3 \\
\hline & $\mid 3 /->/ s /$ & 5.3 & 0.6 \\
\hline & $\mid 3 /->/ j /$ & 73.7 & 9.1 \\
\hline & $|z /->/ t|$ & 5.3 & 0.6 \\
\hline & $/ 3 /->/ d /$ & 5.3 & 0.6 \\
\hline \multirow[t]{4}{*}{$/ \lambda$} & $/ \lambda_{-}>/ 1 /$ & 13.3 & 2.7 \\
\hline & $|N->| \mathrm{r} \mid$ & 60.0 & 12.0 \\
\hline & $\mid N->/ y /$ & 20.0 & 4.0 \\
\hline & $\mid N->/ g /$ & 6.7 & 1.3 \\
\hline \multicolumn{4}{|l|}{ Code (final consonant) } \\
\hline \multirow[t]{2}{*}{$/ \mathrm{r} /$} & $\mid \mathrm{r} /->/ \mathrm{y} /$ & 91.6 & 5.3 \\
\hline & $/ \mathrm{r} /->/ \mathrm{w} /$ & 8.3 & 0.5 \\
\hline \multicolumn{4}{|l|}{ Consonant Cluster } \\
\hline$/ 1 /$ & $/ 1 / \mathrm{EC}->/ \mathrm{r} /$ & 100.0 & 25.9 \\
\hline
\end{tabular}




\section{Discussion}

The results show the pattern of phonological alterations observed in the speech of Brazilian Portuguese speaking apraxics assessed in this study.

Tables 1 and 2 show only consonant segments and no vowels. The higher error rate found in consonants versus vowels has been described elsewhere 2, 4-5, 9. Briefly, this can be explained by the fact that vowels belong to a smaller set of repeatedly activated units and are easier to utter than consonants because the adjustments required to produce vowels are both simpler and slower than consonants, which need faster movements and greater adjustment of several articulators 15 .

Articulation modes of phonemes are presented in Table 1 showing plosives /g/ $(9.2 \%)$ and $/ \mathrm{b} /(6.9 \%)$, the fricatives $/ 3 /(12.2 \%), / \int /(5.5 \%)$ and $/ \mathrm{v} /(5.2 \%)$, and the liquid $/ 1 /(25.9 \%), / \lambda /(20 \%)$ and $/ \mathrm{r} /(5.8 \%)$. No nasal phonemes were observed in this group. Our results for fricative consonants and consonant clusters are in-line with those of international studies 3, 5-7, 11-12. Affricate consonants are often subject to error by apraxics 6-7, but this finding relates more to English speakers, since there are no phonemes with this articulation mode in the Portuguese language. With regard to the high frequency of this type of error in liquid consonants, our findings are congruent with the results of an international study reviewed 7. However, in another study describing the phonemes most subject to speech errors by apraxics 3 , the $/ \lambda /$ phoneme did not rank among the most erroneously produced, yet this phoneme ranked second highest in percentage error in our study, although this is partially explained by its low frequency in the Portuguese language which makes it more prone to error 2, 16-17.

Concerning the place of articulation of phonemes, Table 1 shows bilabial /b/ (6.9\%), labialdental /v/ (5.2\%), alveolar/l/ (25.9\%), /r/ (5.8\%), palatal $/ \lambda /(20 \%)$, $/ 3 /(12.2 \%)$ and / $/$ / (5.5\%), and velar /g/ (9.2\%) involvement. Similar findings are described in the International literature for dental and palatial phonemes 7. Of all the literature studied, only one investigation showed /b/ to be one of the leading errors among this patient population 3 , whereas in general the international studies tend to describe bilabial phonemes as being easier to produce than other phonemes $6,12,17$. In contrast to our results, the palatals $/ \lambda /$ and $/ 3 /$ did not appear high on the scale of phonemes with the greatest percentage of errors in the study describing phonemes most frequently subject to errors by apraxics 3 .
TABLE 2. Frequency of phoneme omissions.

\begin{tabular}{ll}
\hline Phonemes & Omission Frequency $(\%)$ \\
\hline Consonant segments & 8.3 \\
$/ \mathrm{r} /$ & 8.5 \\
$/ \mathrm{R} /$ & \\
Code (final consonant) & \\
/r/ & 10.7 \\
$/ \eta /$ & 5.3 \\
Consonant clusters & \\
/r/ & 26.0 \\
/I/ & 19.8 \\
\hline
\end{tabular}

Our findings partially mirrored results of a phonological study in Portuguese involving a population with speech disturbances of a different etiology - phonological disorder. Akin to the cited study 18 , our results also revealed a higher occurrence of substitutions in the plosive phonemes $/ \mathrm{g} /$ and $/ \mathrm{b} /$, as well as the fricatives $/ 3 /, / \mathrm{J} /$ and $/ \mathrm{v} /$. This comparison was made to determine the extent of specific language interference on phonological alterations, although different variables are known to be associated to phonological disorders in children, rendering comparisons with apraxia of speech rather tenuous. Thus, the substitutions present in the speech of the two populations are believed to have different origins, given that children with phonological disorders present alterations in phonologic acquisition which may be related to difficulties organizing phonological rules of the language, due to cognitive-linguistic problems with auditory perception of sounds and/ or sound production 19. We may therefore speculate that the difficulty regarding these phonemes experience by both groups involves an emission component.

With regard to the types of substitutions which appear for each phoneme (Table 1), the voiced phonemes $/ \mathrm{b} /, / \mathrm{g} /, / \mathrm{v} /$ and $/ 3 / \mathrm{f}$ were found to be more frequently substituted by voiceless phonemes. Studies in the English language have also described devoicing as a characteristic of the apraxic picture and have reported it as the most commonly manifested errors among these individuals 7, 10 . 
Patients with apraxia of speech commit more errors in tasks requiring complex coordinated articulatory movements 12 . These results highlighted that phonemes high in markedness tend to be substituted by unmarked phonemes, thereby making them less complex to produce, in contrast to another study which affirmed that phonemes of low complexity value tend to be substituted by phonemes of higher complexity as opposed to the other way around 20. The same phenomenon occurs with the $/ \mathrm{r} /$ phonemes in code (final consonant), which were predominantly substituted by the semi-vowel $/ y /$, as well as $/ 1 /$ in consonant clusters which was substituted by $/ \mathrm{r} /$ in $100 \%$ of cases.

Table 2 demonstrates the most omitted phonemes. The consonant clusters for both $/ \mathrm{r} /$ and /1/ phonemes were the most subject to this type of error, a finding in line with the literature $3,6-7,11$, as was the finding that omission type errors are more frequently occurring than substitution errors in consonant clusters 7 .

Although several differences are evident upon comparison of our results with those in the literature, several similarities were also observed such as: a lower occurrence of errors in vowels than in consonants 4-5, 9, a higher frequency of errors in fricative consonants and in consonant clusters 3 , 5-7, 11-12; as well as dental and palatal phonemes 7. In addition, studies described devoicing as a characteristic of apraxic conditions 7, 10 and reported a higher rate of articulatory errors in less frequently used stimuli in speech output 2, 16-17. The consensus in the literature is that inconsistency of errors exists in apraxia of speech $3,8,21$, although one of these studies confirmed consistency as being dependent on the phoneme and severity of the apraxic condition 21. Another frequently described characteristic of apraxia of speech was the high frequency of substitution type errors seen in apraxic speech 3-4, 8-9, 22. These manifestations demonstrate the characteristics of speech disorders addressed in this study which, as previously described, are related to alterations in speech motor programming 1, 16, 23-24.

\section{Conclusion}

Although some similarities were observed between error patterns of Portuguese speaking apraxics and apraxic speakers of other languages, it was noted that the phonemes most susceptible to erroneous production by apraxic speakers of Portuguese differed to those reported in international studies. The main differences observed were: substitution of the phonemes $/ \mathrm{b} /$, / $\lambda /$ and $/ 3$ / was highly frequent in the present study. This most likely occurs owing to the phoneticphonologic features of each language, which possesses different corpuses of phonemes, combinatory variants and frequencies of use.

\section{References}

1. Darley FL. Nomenclature of expressive speech-language disorders. Paper presented to Academy of Aphasia meeting. Boston: Mass. 1969;(30).

2. Ortiz KZ. Apraxia de Fala. In: Ortiz KZ, editor. Distúrbios Neurológicos Adquiridos: Fala e Deglutição. $1^{\mathrm{a}}$ ed. Ed. Manole, Barueri, SP. 2006;21-37.

3. Johns D, Darley F. Phonemic variability of apraxia of speech. J Speech Hear Res. 1970;13:556-83.

4. Darley FL, Aronson A, Brown JR. Motor Speech Disorders. Philadelphia: London, Toronto: Saunders; 1975.

5. Canter GJ, Trost JE, Burns MS. Contrasting speech patterns in apraxia of speech and phonemic paraphasia. Brain Lang. 1985;24:204-22.

6. Duffy J. Motor Speech Disorders. St. Louis: Mosby; 1995.
7. Odell K, McNeil MR, Rosenbek JC, Hunter L. Perceptual characteristics of consonant production by apraxic speakers. J Speech Hear Res. 1990;55:345-59.

8. Dronkers NF. A new brain region for coordinating speech articulation. Nature. 1996;384:159-61.

9. Mcneil MR, Robin DA, Schmidt RA. Apraxia of speech: definition, differentiation, and treatment. In: Mcneil MR, ed. Clinical management of sensorimotor speech disorders. New York: Thieme. 1997;311-44.

10. Croot K. Diagnosis of AOS: definition and criteria. Semin Speech Lang. 2002;23(4):267-79.

11. Aichert I, Ziegler W. Syllable frequency and syllable structure in apraxia of speech. Brain Lang. 2004;88:14859. 
12. Ogar J, Slama H, Dronkers N, Amici S, Gorno-Tempini ML. Clinical and anatomical correlates of apraxia of speech. Brain Lang. 2006;97(3):343-50.

13. Martins FC, Ortiz KZ. Proposta de protocolo para avaliação da apraxia de fala. Fono Atual. 2004;30:53-61.

14. Goodglass H, Kaplan EF. The Assessment of Aphasia and Related Disorders. $2^{\mathrm{a}}$ ed. Lea \& Febiger, Philadelphia, PA, USA. 1983.

15. Romani C, Olson A, Semenza C, Granà A. Patterns of phonological errors as a function of a phonological versus an articulatory locus of impairment. Cortex. 2002;38:54167.

16. Cholin J, Levelt WJ, Schiller NO. Effects of syllable frequency in speech production. Cognition. 2006;99(2):205-35.

17. Balasubramanian V, Max L. Crossed apraxia of speech: a case report. Brain Cogn. 2004;55(2):240-6.

18. Mota HB. Aquisição segmental do português: um modelo implicacional de complexidade de traços. Letras de Hoje. Porto Alegre. 1997;32(4):23-47.
19. Wertzner HF, Pagan LO, Galea DES, Papp ACCS. Características fonológicas de crianças com transtorno fonológico com e sem histórico de otite média. Rev Soc Bras Fonoaudiol. 2007;12(1):34-40.

20. Wolk L. Markedness analysis of consonant error productions in apraxia of speech. J Commun Disord. 1986;19(2):133-60.

21. Shuster LI, Wambaugh JL. Token-to-token variability in adult apraxia of speech: A perceptual analysis. Aphasiology. 2008;22(6):655-69.

22. Peach RK, Tonkovich JD. Phonemic characteristics of apraxia os speech resulting from subcortical hemorrhage. J Commun Disord. 2004;37:77-90.

23. Robin DA, Jacks A, Hageman C, Clark HC, Woodworth G. Visuomotor tracking abilities of speakers with apraxia of speech or conduction aphasia. Brain Lang. In press 2008 jun.

24. Maas E, Robin DA, Wright DL, Ballard KJ. Motor programming in apraxia of speech. Brain Lang. In press 2008 apr. 